https://doi.org/10.15407/mineraljournal.42.02.014

УДК 552.513:553.661.2(477.61/62)

L.F. Mametova, PhD (Geology), Senior Research Fellow.

M.S. Polyakov Institute of Geotechnical Mechanics of the NAS of Ukraine

49005, Dnipro, Ukraine, Simferopolska Str., 2a

E-mail:wolya45@gmail.com

https://orcid.org/0000-0001-6198-7337

A. Mirek, Candidate of Technical Science, President.

State Mining Authority

40-055 Katowice, Poland, Poniatowskiego Str., 31

E-mail: prezes@wug.gov.pl

https:/ / orcid.org/0000-0002-2824-8177

Ye.S. Kozii, PhD (Geology), Deputy Director.

Dnipro University of Technology

49005, Dnipro, Ukraine, Dmytro Yavornytskyi Ave., 19

E-mail: koziy.es@gmail.com

https:/ / orcid.org/0000-0002-2167-6224

\title{
PYRITIZATION OF THE MIDDLE CARBONIFEROUS SANDSTONES OF THE DONBAS
}

\begin{abstract}
Coal mining is linked with such phenomena as sudden gas outburst, explosions, and ignition of coal seams. Among the preconditions for explosions, emissions and possible inflammations, the process of pyritization of rocks of the geological cross-sections of the Donbas basin is poorly known, and the transformation of accessory pyrite minerals has not been studied. The purpose of the work is research of the pyritization of Carboniferous sandstones of coal-bearing sediments of this basin. Diagenetic and catagenetic pyrite can be distinguished. The investigation of secondary (catagenetic) mineral transformation of terrigenous coal deposits shows the interaction of geochemical and tectonic processes. Pyritization is part of a geochemical process, they occur discretely in coalbearing strata. Catagenesis is accompanied by the phenomenon of heating and burning. Pyrite activates these phenomena, and promotes the burning of coal seams and gases. The authors demonstrate a highly variable distribution of ferrous compounds in a sandstone layer either along-strike or across layer thickness. Variations in the content of $\mathrm{FeS}_{2}$ can be related to the transformation of marcasite to pyrite. The results can be the basis for the development of criteria for assessing the tendency of coal deposits to spontaneous combustion.
\end{abstract}

Keywords: pyrite, sandstones, pyritization, spontaneous combustion of coal seams, explosions, emissions, geological crossection, Donbas.

Introduction. Geological exploration of rocks of coal deposits pursue the aim to understand and determine the nature of the generation of mineral deposits, to provide their safe extraction.

Long-term coal mining is linked with such phenomena as: sudden coal-and-gas outburst, explosions and coal fires. The works of V.E. Zabihailo [6-8], V.I. Nikolin [7], V.I. Saranchuk [19], M.P. Zborshchyk [9], A. Mirek [21] and others were devoted to their research. There were continued work on the determination of emission factors not only in coal, but also in sandstones of different genetic types $[1,8,12,20]$. A qualitative and quantitative variance in the properties of rocks and minerals has been established $[6,13$, 14]. Criteria have been determined for separation in to catagenesis substages $[3,12,13,20]$. But in characterization of the geological conditions 
of catagenesis and formation of preconditions for explosions, bursting and possible spontaneous combustion, the processes of pyritization of rocks of all geological cross-section have been poorly known, and the transformations of pyrite satellite minerals have not been studied.

The purpose of this article is to research the pyritization of sandstones of coal-bearing sediments of Donets basin.

The object of research is the process of catagenetic transformations in the sandstones of the coalbearing suites $\left(\mathrm{C}_{2}{ }^{3}-\mathrm{C}_{2}{ }^{7}\right)$ of the Middle Carboniferous of Donbas.

A complex study of the lithology of coal-bearing sediments made it possible to establish stadial mineralogical and geochemical changes in rocks $[1,3$, $5,12,15,16]$, to compare the transformations of coal matter and minerals in the composition of rocks $[5,10,16,17]$, to determine the factors creating critical situations: explosions, fires, etc. Research of coal deposits of different depths and different degrees of transformations revealed among them mineral formations, which include chemical elements of variable valence $(\mathrm{Fe}, \mathrm{S})$. In the geologic cross-section of Donbas among siltstones, mudstones, sandstones and coal seams they are present in the minerals: pyrite, marcasite $\left(\mathrm{FeS}_{2}\right)$, melnikovite $\left(\mathrm{Fe}_{5} \mathrm{~S}_{7}\right)$, pyrrhotite $\left(\mathrm{Fe}_{1-n} \mathrm{~S}\right)$, siderite $\left(\mathrm{FeCO}_{3}\right)$, ferrous sulfates $\left(\mathrm{FeSO}_{4}\right)$. Pyrite is observed in the form of individual crystals, inclusions, sometimes lenticular clusters and interlayers in rocks and coal seams [3,11-14, 16]. Interlayers and lenses are located in accordance with the general bedding of rock mass. The form of crystals is cubic, octahedral. Sometimes it is globular forma- tions with size from 0.5 microns to 10 microns [16]. Together with pyrite in sandy-argillaceous sediments also marcasite is found, often in nodules. Its chemical compound is similar to pyrite. The main difference in the structure: rhombic syngony marcasite and pyrite - cubic. The grain shape of marcasite is notched, in nodules it is radiant, and it also forms "scallops" of accretion. At a temperature of $350{ }^{\circ} \mathrm{C}$ marcasite gradually turns into pyrite. The primary genesis of marcasite is noted in the works of N.V. Lohvynenko [15], P. Ramdor [18] and others. In comparison with pyrite and marcasite, melnikovite meet rare - mainly in coal seams. pyrrhotite was incorrectly called as magnetic pyrite. It belongs to the hexagonal system and differ of higher iron content (up to 63.5\%). Its magnetic properties are lost at $348^{\circ} \mathrm{C}[14,18]$, it rarely forms crystals, it is unstable. With pyrite and marcasite, pyrrhotite is associated with a mutual transition - during heating and low sulfur vapor pressure.

Petrographic research of sandstones of coalbearing sediments in 7 areas of Donbas have shown that there is pyrite of two generations: diagenetic and catagenetic $[3,13,16]$. The first generation is in the form of an accessory mineral between fragments in sandstone cement. The second generation was formed in the process of postsedimentary (catagenetic) transformations with rocks [16].

Active participation in the process takes dispersed organic matter. Catagenesis is a complex, multifaceted process of interaction between sedimentary rocks, stratal waters, dispersed organic matter, and various gases. It occurs under conditions of increasing temperature and pressure. Many

Table 1. Stages of rock transformation

\begin{tabular}{|c|c|c|}
\hline \multicolumn{2}{|l|}{ Stage } & \multirow{2}{*}{ Thermodynamic conditions } \\
\hline According to $[1,3,5,6,8,10,12,15,16]$ & According to [20] & \\
\hline Diagenesis & Diagenesis & $\begin{array}{c}\text { Temperature nearly to surface, } \\
\text { Pressure to } 1-3 \mathrm{MPa}\end{array}$ \\
\hline \multirow{3}{*}{$\begin{array}{l}\text { Early catagenesis (coal of rank: } \mathrm{D}, \mathrm{G})^{*} \\
\text { Middle catagenesis (coal of rank: } \mathrm{G}, \mathrm{Zh}, \mathrm{K}, \mathrm{OS})^{*} \mathrm{MC}_{2}-\mathrm{MC}_{5} \\
\text { Late catagenesis (coal of rank: OS, T, A)* }\end{array}$} & Protocatagenesis (PC) & $50-70^{\circ} \mathrm{C}$ \\
\hline & Mesocatagenesis (MC) & $90-150^{\circ} \mathrm{C}$ \\
\hline & Apocatagenesis (AC) & $170-220^{\circ} \mathrm{C} ; 100 \mathrm{MPa}$ \\
\hline $\begin{array}{l}\text { Early metagenesis }(\mathrm{A})^{*}[5,12] \\
\text { Late metagenesis }(\mathrm{A})^{*}[5]\end{array}$ & Metagenesis & $\begin{array}{c}270{ }^{\circ} \mathrm{C} \\
200-350^{\circ} \mathrm{C} \\
>200 \mathrm{MPa}[3]\end{array}$ \\
\hline Regional metamorphism & & $400-450^{\circ} \mathrm{C}$ \\
\hline
\end{tabular}

N o t e. * (1997) DSTU 3472-96. Brown coals, hard coals and anthracite. Classification, Derzhstandart Ukrainy, Kyiv, UA [in Ukrainian]. 


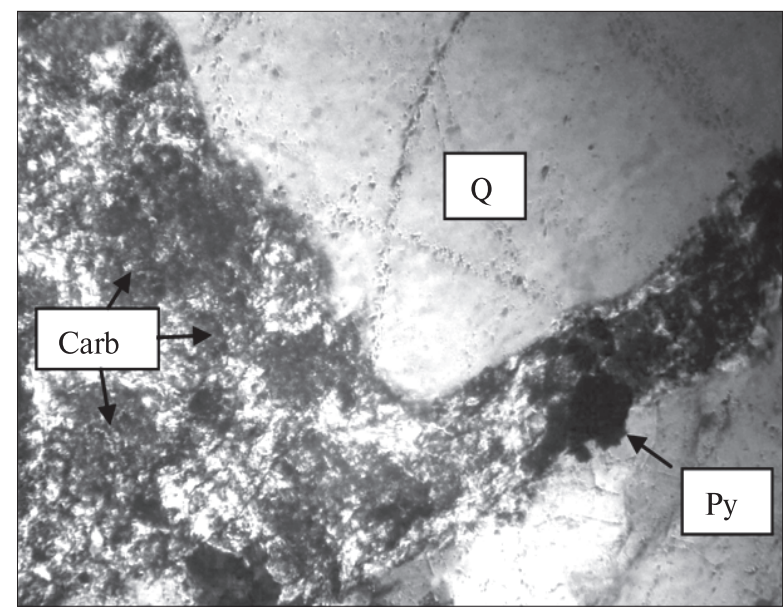

Fig. 1. Pyrite (Py) and microspherulites of carbonates (Carb) between quartz grains $(\mathrm{Q}), \mathrm{MC}_{2}$. Crossednicols, $677 \times 506 \mathrm{mkm}$

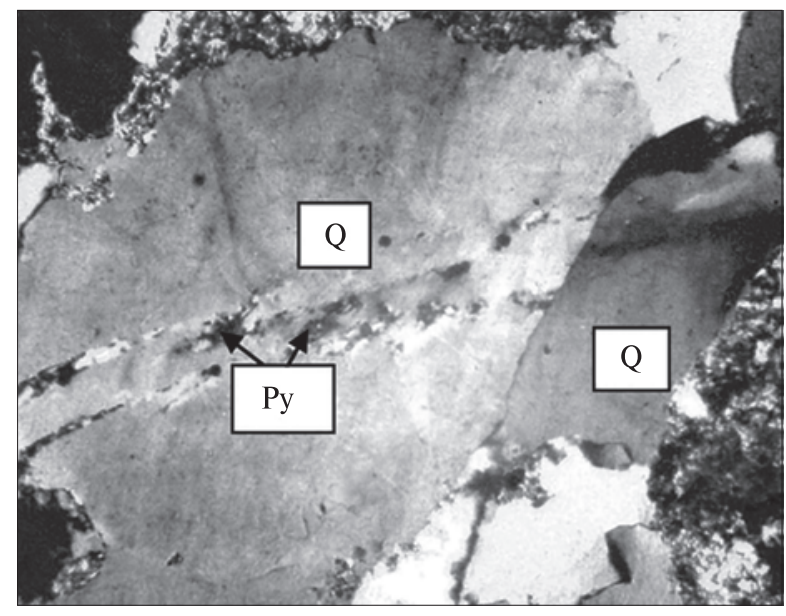

Fig. 2. Pyrite (Py) in microdeformations of quartz grain $(\mathrm{Q})$ of Almazna suit sandstone $\left(\mathrm{C}_{2}{ }^{6}\right), \mathrm{MC}_{5}$. Crossednicols, $677 \times 506 \mathrm{mkm}$

Table 2. Thermal conditions of catagenetic changes in rocks of Middle Carbon, ${ }^{\circ} \mathrm{C}$

\begin{tabular}{|c|c|c|c|}
\hline Stage & V.A. Baranov, 1989 [1] & E.I. Derevska, 2002 [5] & V.A. Pryvalov, 2005 [17] \\
\hline Protocatagenesis & - & 110 & - \\
\hline Early Catagenesis $\mathrm{MC}_{1}$ & (Coal of rank D) & 120 & $60-80$ \\
\hline Middle Catagenesis & & & \\
\hline $\mathrm{MC}_{2}$ & $100-130($ coal of rank $G)$ & 140 & $80-130$ \\
\hline $\mathrm{MC}_{3}^{2}$ & $120-140$ (coal of rank $\mathrm{Zh}$ ) & (coal of rank: Zh, K, OS) & \\
\hline $\mathrm{MC}_{4}$ & $140-160$ (coal of rank K) & & \\
\hline $\mathrm{MC}_{5}$ & $160-180$ (coal of rank OS) & & \\
\hline Late Catagenesis $\mathrm{AC}_{1}-\mathrm{AC}_{2}$ & $180-220($ coal of rank T) & 155 & $130-170$ \\
\hline Early Metagenesis & - & 190 & $170-200$ \\
\hline Late Metagenesis & - & 270 & $200-250$ \\
\hline
\end{tabular}

Table 3. Mineral composition and content of iron compounds in sandstone [4]

\begin{tabular}{|l|c|c|c|c|c|c|}
\hline \multirow{2}{*}{$\begin{array}{c}\text { Place } \\
\text { of sampling }\end{array}$} & Total compression & E-modulus $\left(10^{-4}\right)$ & $\begin{array}{c}\mathrm{S}, \text { total } \\
\text { content }\end{array}$ & $\begin{array}{c}\text { Water sulphates } \\
\left(\mathrm{FeSO}_{4} \cdot n \mathrm{H}_{2} \mathrm{O}\right)\end{array}$ & $\begin{array}{c}\text { Siderite } \\
\left(\mathrm{FeCO}_{3}\right)\end{array}$ & Pyrite $\left(\mathrm{FeS}_{2}\right)$ \\
\cline { 2 - 7 } & \multicolumn{2}{|c|}{$\mathrm{MPa}$} & \multicolumn{5}{|c|}{$\%$} \\
\hline Pc 26.1 & 68.2 & 1.27 & 6.27 & 41.02 & 53.37 & 5.6 \\
Pc 26.2 & 71.4 & 0.93 & 10.34 & 22.11 & 74.92 & 2.96 \\
Pc $15+8$ & 74.9 & 1.3 & 6.02 & 14.96 & 80.54 & 4.51 \\
\hline
\end{tabular}

$\mathrm{N}$ o t e. Pc - Picket number in mine.

researchers recognizing the process of cyclicity, distinguish in different ways the stages and substages of changes (Table 1).

By way of observations and experiments $[3,9$, $12,13,15,18]$ it has been established: for the formation of pyrite, a sharply regenerative condition is needed in which hydrogen sulfide and its compounds appear. Siderite occurs during the partial oxidation of organic substances and determines the transition phase from a strictly anaerobic environment to conditions with a weak access of oxygen. Precisely these reactions characterize the beginning of middle substage of catagenesis $\left(\mathrm{MC}_{2}\right)($ Table 2).

Over our observations at the beginning of the middle substage $\left(\mathrm{MC}_{2}\right)$ at the same time pyrite and spherulites of carbonate formed (Fig. 1).

Geochemical variation in the composition of pore solutions and an increase pressure at the end of this substage, $\mathrm{MC}_{5}$, caused the formation of pyrite only. With a change of geodynamic regime, take place a rock deformation and their minerals, 
fractures appear with pyrite and new quartz generation (Fig. 2).

Activation of tectonic movements have an impact on the intensity of catagenesis, promotes the migration of solutions, on the emergence of new minerals (calcite, pyrite of second-generation, sulfates, etc.), on the oxidation of diagenetic pyrite and marcasite (up to limonite) and various mineral transformations of rocks. In this case, a lot of sulfuric acid is released and all the iron in the form of ferrous sulfates is removed. The final product of the hydrolytic splitting of sulfates is limonite. By chemical analysis recorded the presence of water sulphates: pickeringite, halotrichite and other iron compounds in sandstones of coal-bearing strata, for example, in Almazna suite $\left(\mathrm{C}_{2}{ }^{6}\right)$ (Table 3 ).

Methods. The main methods of knowledge of geological processes in rocks are petrographic, mineralogical research supplemented by definitions of chemical and physical properties of rocks. The petrographic description of thin rock sections (in the quantity of 435) was carried out using a POLAM R-111 polarizing microscope. The mineralogical composition was determined by the method of Mössbauer spectroscopy. Illustrative photo were made by the DSM-200 camera.

Results and Discussion. Our research has established: $a$ ) close indicators of sulfur (S, total content) and a significant difference in the content of siderite -1 and 3 samples - indicate the carbonate composition of the migrating solutions; $c$ ) contrasting fall in the content of water sulphates, it is our opinion that, it is connected with a decrease of total moisture, stimulating hydrolytic reactions and different sampling depth. Variations in the content of $\mathrm{FeS}_{2}$ can be related with the transformation of the minerals structure - the transition of marcasite to pyrite. The ability to oxidize is remained. Siderite is present in the form of nodules and spherulites, it is easily hydrolyzed at all levels of the middle substage of catagenesis. Therefore, the ratio of pyrite iron $-\mathrm{FeS}_{2}$ - to siderite iron $\mathrm{FeCO}_{3}-$ can be an indicator of the degree of regenerative of the conditions $[4,16]$. In areas of sudden coal squeeze was noted reduction of total iron content in layer and increase in roof rocks (sandstone, mudstone) [4]. According to the results of our observations, sandstones of the Middle Carboni- ferous are characterized by an uneven distribution of iron compounds along the strike and thickness of the layer. According to the results of our observations, sandstones of the Middle Carboniferous are characterized by irregular distribution of iron compounds along the spread and thickness of the layer. Such irregularity can dramatically change the physical and mechanical characteristics of the rock mass and lead to dislocating of its stability.

Except variations in chemical composition catagenesis also affects on thermo-electrical properties of pyrite [13, 14]. During temperature of $120^{\circ} \mathrm{C}$, the modal definitions of thermo-electromotive force (thermo-emf.) are equal to -100 and +100 $\mathrm{mkV} / \mathrm{deg}$. The following changes [12] in terrigenous sediments and coal led to the recrystallization of pyrite and took place during thermo-emf. $300-350 \mathrm{mkV} / \mathrm{deg}$ and temperature indicator $180-220^{\circ} \mathrm{C}$.

Rocks of geologic cross-section of coal deposits from the action of catagenesis factors (changes in temperature, pressure, etc.) undergo destruction with the release of heat and combustible substances. The most widespread example can be called as process of rocks self-heating. One of the reason is the oxidation of pyrite with the following release of sulfuric acid and iron sulfate. It is this chemical reaction that often causes spontaneous combustion of coal seams $[9,15,19]$. Pyrites originated from pyrrhotite are capable of igniting, especially in wet coals. According to V.A. Baranov [2] "The ignition of coal can also occur as a result of emissions and explosions, rock movement during shrinkage, when a spark tracking occurs in quartz during triboelectric charging or piezoelectric effect; the presence of pyrite in coal or in the rock leads to a pyroelectric effect" [2].

Conclusions. To improve the safety of work at coal enterprises, it is necessary to continue research of oxidation of sulfides in rocks and coal seams through the stages of coal maturation linked with catagenesis and metagenesis. The different constitution of crystal structure of minerals impact on the nature of the transformation of rocks, physical properties of the rock mass. The results can be the basis for the development of criteria for assessing the tendency of coal deposits to spontaneous combustion during displaying various gas-dynamic phenomena. 


\section{REFERENCES}

1. Baranov, V.A. (1989), Micronarushennost kvartsa peschanikov Donbassa v svyazi s ikh vyubrosoopasnostuy, Abstr. PhD dissertation, UA, 17 p. [in Russian].

2. Bulat, A.F., Yashenko, I. and Baranov, V.A. (2017), Ugol' Ukrainy, No. 11-12, UA, pp. 30-44 [in Russian].

3. Vikulov, O.G. (2002), Piritizatsiya v litogeneze uglenosnykh otlozheniy srednego karbona Donbassa, Abstr. PhD dissertation, Moskva, RNU, RU, 24 p.

4. Gladkaya, E.V., Gavrilyuk, V.G., Vinnik, E.A., Mametova, L.F. and Skoblik, A.P. (2013), Materialy XXIII Mezhdunar. nauch. shkoly im. akademika S.A. Khristianovicha, Simferopol, UA, pp. 83-85 [in Russian].

5. Derevska, K.I., Shumlianskyi, V.O. and Novik, V.A. (2002), Zb. nauk. prats IGN NAN Ukr., Vol. 1, Kyiv, UA, pp. 55-72 [in Ukrainian].

6. Zabihailo, V.U., Lukinov, V.V. and Shyrokov, O.Z. (1983), Vybrosoopasnost' gornykh porod Donbassa, Nauk. dumka, Kyiv, UA, 288 p. [in Russian].

7. Zabihailo, V.U. and Nikolin, V.I. (1990), Vliyanie catageneza gornykh porod i metamorfizma ugley na ikh vybrosoopasnost', Nauk. dumka, Kyiv, UA, 168 p. [in Russian].

8. Zabihailo, V.U., Shyrokov, O.Z., Bilyi, Yo.S., Kudelskyi, V.V., Mossur, K.A. and Rudometov, B.P. (1974), Geologicheskie factory vybrosoopasnosti porod Donbassa, Nauk. dumka, Kyiv, UA, 270 p. [in Russian].

9. Zborshchik, M.P. and Osokin, V.V. (2000), Gorenie porod ugolnykh mestorozhdeniy i ikh tushenie, DonSTU, Donetsk, UA, 180 p. [in Russian].

10. Karpova, G.V. (1972), Glinistye mineraly i ikh evolyuytsiya v terrigennykh otlozheniyakh, Nedra, Moskva, RU, 174 p. [in Russian].

11. Koziy, Ye.S. (2018), Dnipropetrovsk Univ. Bull. Ser. Geol.-Geography, No. 1 (26), pp. 113-120 [in Ukrainian]. doi. org/10.15421/111812

12. Kurylo, M.V. (2001), Actualni problemy geologii Ukrainy, Publ. and Printing Center "Kyivskyi Universytet", Kyiv, UA, pp. 17-18 [in Ukrainian].

13. Lazarenko, E.K., Panov, B.S. and Pavlyshyn, V.I. (1974), Mineralogiya Donetskogo basseyna, Nauk. dumka, Kyiv, UA, pp. 259-286 [in Russian].

14. Lazarenko, Ye.K. and Vynar, O.M. (1975), Mineralogichnyi slovnyk, Nauk. dumka, Kyiv, UA, 772 p. [in Ukrainian].

15. Lohvinenko, N.V. (1968), Postdiageneticheskie izmeneniya osadochnykh porod, Nauka, Moskva, RU, 91 p. [in Russian].

16. Mametova, L.F. (2012), Geotekhnichna mekhanika, No. 102, UA, pp. 183-189 [in Ukrainian].

17. Pryvalov, V.A. (2005), Tektonothermal evolution of the Donets Basin, Abstr. Dr. Sci. Dissertation, Nac. Gornyi Univ., Dnipropetrovsk, UA, 35 p. [in Ukrainian].

18. Ramdor, P. (1962), Rudnye mineraly, Inostrannaya literatura, Moskva, RU, pp. 765-777; 806-812 [in Russian].

19. Saranchuk, V.I. (1982), Okislenie i samovozgoranie uglya, Nauk. dumka, Kyiv, UA, 168 p. [in Russian].

20. Vassoievych, N.B., Librovych, V.L. and Lohvinenko, N.V. (1983), Spravochnik po litologii, Nedra, Moskva, pp. 85-128 [in Russian].

21. Patyńska, R., Mirek, A., Burtan, Z. and Pilecka, E. (2018), Rockburst of parameters causing mining disasters in Mines of Upper Silesian Coal Basin, E3S Web of Conferences, BIG 2018 - 4th Nationwide Sci. Conf. on Engineering-InfrastructureMining, 36. https://doi.org/10.1051/e3sconf/20183603005

Received 29.01.2020

Л.Ф. Маметова, канд. геол. наук, старш. наук. співроб.

Інститут геотехнічної механіки ім. М.С. Полякова НАН України

49005, м. Дніпро, Україна, вул. Сімферопольська, 2а

E-mail: wolya45@gmail.com

https://orcid.org/0000-0001-6198-7337

A. Мірек, канд. техн. наук, президент.

Державний гірничий нагляд

40-055, м. Катовіце, Польща, вул. Понятовського, 31

E-mail: prezes@wug.gov.pl

https://orcid.org/0000-0002-2824-8177

C.C. Козій, канд. геол. наук, заст. дир. Навч.-наук. центру

Національний технічний університет "Дніпровська політехніка"

49005, м. Дніпро, Україна, пр-т Дмитра Яворницького, 19

E-mail: koziy.es@gmail.com

https://orcid.org/0000-0002-2167-6224

\section{ПІРИТИЗАЦІЯ ПІСКОВИКІВ СЕРЕДНЬОГО КАРБОНУ ДОНБАСУ}

Багаторічний видобуток вугілля пов'язаний із такими явищами як раптові викиди газу, вибухи і загоряння вугільних пластів. Процеси піритизації порід усього геологічного розрізу, формування передумов, що відбуваються під час вибухів, викидів і можливих загорянь вивчені мало, не досліджені і перетворення мінералів-супутників піриту. Мета роботи - дослідити піритизацію пісковиків вугленосних відкладів середнього карбону Донецького 
басейну. На підставі результатів дослідження вторинних (катагенетичних) перетворень мінералів теригенної товщі вугільних родовищ установлено взаємодію геохімічних і тектонічних процесів. Піритизація - це частина геохімічних процесів, вони відбуваються дискретно і за умовами утворення виділяються діагенетичний i катагенетичний пірит. На відмінність між ними впливали параметри катагенезу (температура, тиск, склад розчинів та ін.), їх стадійні коливання. Катагенетичні різновиди на початку середньої підстадії спостерігались разом 3 мікросферолітами карбонатів між зернами, рідше - по контуру уламкових зерен. Збільшення параметрів катагенезу до кінця цієї підстадії спричиняли утворення тільки піриту. В деформаційних смужках кварцу, польових шпатів також присутній пірит. Катагенез супроводжується явищами нагрівання і загоряння. Пірит активізує ці явища, сприяє займанню вугільних пластів і газів. Установлено нерівномірний розподіл сполук заліза за простяганням і потужністю пісковиків і на контакті з вугільними пластами. Варіації вмісту $\mathrm{FeS}_{2}$ пов'язані 3 перетворенням структури мінералів - переходом марказиту в пірит, піротину в пірит. Різна будова кристалічної гратки мінералів, їх катагенетичні перетворення впливають на фізичні властивості гірського масиву. Отримані результати можуть бути основою для розробки критеріїв оцінювання вірогідності самозаймання порід вугільних родовищ, стимульованого катагенезом і газодинамічними явищами.

Ключові слова: пірит, пісковики, піритизація, займання вугільних пластів, вибухи, викиди, геологічний розріз, Донбас.

Надійшла 29.01.2020 